ARTICLE

DOI: $10.1057 /$ s41599-018-0065-0

\title{
In digital we trust: Bitcoin discourse, digital currencies, and decentralized network fetishism
}

Jon Baldwin ${ }^{1}$

\begin{abstract}
This paper outlines how the digital currency and network technology of bitcoin functions and explores the context from which it emerged. Bitcoin was conceived in 2008 as an attempt to alleviate trust in government and banks which was at a low during this period of financial crisis. However, with bitcoin trust does not dissipate, rather it shifts. Trust moves from trust in banks or states to trust in algorithms and encryption software. There is a move from conventional trust in the gold standard-"In Gold We Trust"-to the trust announced on U.S. currency - "In God We Trust" - to trust in software and networks-"In Digital We Trust". The hyperbole of bitcoin discourse is deemed to be an expression of the Californian Ideology, which itself often conceals a right-wing agenda. The paper analyses the hype behind the celebration of decentralised digital networks. It proposes that a form of network fetishism operates here. The failure of bitcoin as a currency (rather than as a hoarded commodity in an emergent bubble) and as an idea might be attributed to the failure to see how ultra-modern digital networks conceal very traditional consolidation of power and capital. The rise and fall of bitcoin, in terms of its original ambition, serves as a cautionary tale in the digital age-it reveals how ingenious innovations that might challenge power and the consolidation of capital become co-opted and colonised by capital. Finally, the paper offers a discussion of the possible progressive uses of the digital technology bitcoin has facilitated.
\end{abstract}

\footnotetext{
${ }^{1}$ London Metropolitan University, London, UK. Correspondence and requests for materials should be addressed to J.B. (email: j.baldwin@londonmet.ac.uk)
} 


\section{Introduction-bitcoin, the uberfication of money}

- o put it simply to begin, in what was once considered a positive attribute in the rhetoric of the digital economy, bitcoin $^{1}$ is the Uberfication ${ }^{2}$ of money. With Uber, peers can connect and make travel arrangements within a network without the need for mediation with a central node (a regulated taxi firm, for instance). Likewise, with bitcoin. Peers can connect and make financial exchanges within a network without the need for mediation with a central node (a bank, financial institution, or government). The motivation behind the design and development of the digital currency and its software, was to utilise the Internet to establish a form of "peer-to-peer electronic cash system" (Nakamoto, 2009). This would be an immaterial form of money in which there is no need for mediation with, or trust in, traditional financial institutions. The motto "In God We Trust" has appeared on U.S. paper currency since 1957. Bitcoin, as a digital cryptocurrency signals a shift in confidence to "In Digital We Trust." Since its introduction in 2008, bitcoin has been widely championed in some quarters as being independent of any thirdparty control such as government or a central bank. Cyber-libertarians, techno-utopians, venture capitalists and others have celebrated bitcoin as a digital currency that can challenge the global economic order, facilitate forms of freedom, be a decentralising force for good, and revolutionise everything from online commerce to the nation-state.

On the one hand, such digital initiatives belong to a naïve moment in the development of the Internet ${ }^{3}$ when the likes of the Wired magazine milieu told us and sold us the coming of a networked society, in which old hierarchical models of business and culture would be superseded by the wisdom of crowds, usergenerated content, and an ethos of transparency and collaboration. This prospect looks extremely remote just half a decade later, and so there is a very real sense in which bitcoin is already out of date. On the other hand, the development and operations of digital currencies such as bitcoin, can illuminate the emergent digital economy, its discourse, and its discontents. The digital economy-that is, businesses that rely upon the speed and flows of information technology, the internet, and data-has a purported dynamism. As such, it is increasingly presented as a hegemonic model and ideal that can legitimate contemporary capitalism more broadly. (Srnicek, 2017, p 5) The apparent future of capitalism is at hand in digital economies and bitcoin serves as a prototype digital currency of this economy.

\section{Bitcoin as digital money}

Bitcoin is an attempt to establish an autonomous decentralised digital currency and payment system, making online transactions purely peer-to-peer without centralised mediation. It implements cryptography as a means of verifying and securing online transactions. A bitcoin is an electronic coin, designed and defined by Nakamoto $^{4}$ (2008) as "a chain of digital signatures." It has no physical quality, being nothing more than an entry on a digital ledger. When a digital transfer is made the owner leaves an identifying signature validating legitimate acquisition of the coins and a unique public key of the next owner. The receiver can trace the attached signatures to "verify the chain of ownership." (Nakamoto, 2008) Transactions are broadcasted and then "timestamped" to prevent double spending. External nodes, or individual CPUs, create a peer-to-peer network that can legitimise transfers and stores this information in a block. A block will contain the transaction history and a complex mathematical algorithm. Nodes subsequently compete to solve these algorithms, and when successful create a new block-this is referred to as mining for coins. ${ }^{5}$ The successful node wins a new bitcoin and this is the incentive for both the maintenance of the network and the honesty of nodes. In this apparently anonymous ${ }^{6}$ and decentred way, bitcoin does not rely on a central authority or central node to disseminate and regulate the currency. The network itself does this and maintains the bitcoin's nominal value. The blockchain is presented as an algorithmic tool to foster trust in the absence of things like social capital, physical colocation, or trusted third-party management. This unregulated virtual currency, issued and controlled by its developers, has stepped out of its self-reference to be exchanged for legal tender. This is an innovative use of digital technology and cryptology, but what backs up the value the bitcoins seemed to have on paper? Essentially a new form of trust: "The primary value the coins had was the expectation that they would be worth more in the future, allowing current holders to cash out for more than they paid" (Popper, 2015, p 285). Should the trust and willingness of market participants to exchange fiat currency for bitcoin erode and end then this will result in the potential for permanent and total loss of value of bitcoin. In this sense, bitcoin can be argued to resemble a Ponzi scheme.

Money, markets, and finance, as they have evolved, have had a crucial relationship with technology. Key moments might include the development of writing in ancient Sumer, and the recording of inventory and trade; the popularisation, emerging in Renaissance Italy, of the balance sheet and banks whereby the different transactions in a society can be gathered together in a single register; the invention of the central bank, with the foundation of the Bank of England in 1694, and the subsequent development of the right to print paper money. (Lanchester, 2016) More recent is the change from commercial fairs to financial markets, whereby "the goods were not exposed anymore and the transactions (on paper) became symbols" (Schinckus, 2008, p 1086). The Iowa Electronic Market, created in 1988, was the first virtual market where all interactions took place online. In brief, this encapsulates the broad narrative of the dematerialisation of money outlined by Goux (1994) whereby money passes through three stages-from gold (or metallic or material money) to paper (a representation of money) to the era of immaterial digital and credit money. Bitcoin is an emergent dematerialised digital currency.

The development of automatic trading and the creation of electronic financial products have profoundly modified the organisation of markets and financial exchanges themselves. Today's digital monies can be viewed as forms of language-or more specifically, writing or code-in their own right. The key analytical issues they raise are no longer principally about value and representation-as in gold and paper money-but rather security and encryption. As Dodd claims, "[i]t is no accident that such concerns coincide with the era of financialisation, in which money has become increasingly self-referential" (Dodd, 2014: 36). The development of financialization, ${ }^{7}$ concomitant with technological changes, has not necessarily improved financial affairs for the majority. Rather it has facilitated the capitalist trend toward monopolistic power, consolidated, intensified, and legitimated neoliberalism, and resulted in periods of boom and bust, arguably leading most recently to the sub-prime mortgage financial crash of 2008. Indeed, following the insights of Piketty (2014), wealth and power have concentrated enormously in the era of the digital economy, "as digital technology has spread all around the globe" (Golumbia, 2016, p 11), precisely in the name of vague slogans like speed, efficiency, connectivity, and "internet freedom."

\section{The context of bitcoin: the hyper-real economy and financial crash of 2008}

The context of bitcoin is the hyper-real economy (Baldwin, 2013) emerging from the confluence of the abandonment of the gold 
standard (1971), the processes of quantification of phenomena, the growth of financialization, and the realisation of the digital society and New Economy. The latter includes high-technology industry, business and financial services, lending and speculation, the media, and e-cultural industries. Bitcoin, and its blockchain technology, is a form of dematerialised money, a pure token devoid of any connection to an underlying material substance, money created ex nihilo, and as simulacra without reference to the real. With bitcoin, "money can be created out of nothing, i.e., from within the network itself" (Dodd, 2014, p 363). Bitcoin then, as a virtual currency in a virtual network, is thoroughly reliant upon new digital technologies, and interestingly itself claims to have arisen as a response and solution to the crash of 2008.

The bailout of the banks in response to the crash of 2008-a socialist solution to a capitalist problem-is suggested to be crucial in the impetus behind bitcoin. There may be some opportunism here, however bitcoin was launched in a paper published on 31 October 2008 under the name Satoshi Nakamoto. This date was shortly after the collapse of Lehman Brothers on 15 September 2008, and the near crash of the global financial system. In what is known as the Genesis block, the very first block of data in bitcoin, there was a concealed message stored in the coinbase. Along with the standard data, the original transaction also contains the message: "The Times 03/Jan/2009 Chancellor on brink of second bailout for banks" ${ }^{8}$ This is an attempt to reference a perceived problem with the government and banks, and make a contrast between bitcoin and conventional banking. In launching bitcoin as a peer-to-peer currency, Nakamoto (2009) suggests:

The root problem with conventional currency is all the trust that's required to make it work. The central bank must be trusted not to debase the currency, but the history of fiat currencies is full of breaches of that trust. Banks must be trusted to hold our money and transfer it electronically, but they lend it out in waves of credit bubbles with barely a fraction in reserve. We have to trust them with our privacy, trust them not to let identity thieves drain our accounts.

Trust in government and banking was at a low in the 2008 crash period and Nakamoto makes capital out of this. However, with bitcoin trust does not dissipate, rather it shifts. Trust moves from trust in banks or states to trust in algorithms and encryption software. ${ }^{9}$ There is a move from conventional trust in the gold standard-"In Gold We Trust," to the trust announced on U.S. currency-"In God We Trust," to trust in software and networks — "In Digital We Trust." This signals a fundamental shift in digital culture.

\section{Bitcoin discourse}

The trust and belief in bitcoin as a remedy to purported problems with traditional finance has been reflected in the popular discourse around bitcoin. There is hyperbole, half-truth, and excitement here and much blurring in this discourse between bitcoin as currency, bitcoin as technology, bitcoin as the free market realised, bitcoin as commodity, bitcoin as investment, cryptocurrency as in bitcoin, cryptocurrency in general, the blockchain as in bitcoin, or the blockchain as in general. Digital discussion is discomfortingly reliant on the Californian Ideology and business, journalistic, investor, and enthusiast commentary regarding the apparent utopian impact of digital technologies on economies and societies in the twenty first century. This discourse is not disinterested. As Fisher suggests, "the discourse on technology is not a transparent vignette on reality but rather a particular outlook on it...technology not only constitutes the material foundations of modern societies but also functions as its legitimation"
(Fisher, 2010, p 2). A trading firm research analyst has announced that, "[w]e see the intrinsic value of Bitcoin as the conduit in a new global crowd-funded open-source payment network" (in Popper, 2015, p 347). Bitcoin has been described, by various enthusiasts, as "the internet of money" (Popper, 2015, p 430) and the "first online currency based on highly distributed trust" (Popper, 2015, p 434). Somewhat immodest claims have been made on behalf of the possibilities of bitcoin: It "will replace the current financial system" (Falkvinge in Golumbia, 2016, p 81); it is to money what the Internet was to property, "with Bitcoin giving people control over their money and trade again, [there is] the potential for a monumental shift in the power structure of the world" (Barber, 2015); and it is posited "as the new First Amendment app" (Falkvinge in Golumbia, 2016, p 67). It is announced that the bitcoin "blockchain is as revolutionary today as were personal computers in 1975, and the internet in 1993" (Andreessen in Golumbia, 2016, p 87). One early adopter excitedly exclaimed that it is, "the first thing I know where you can both get rich and change the world" (Voorhees in Popper, 2015, p 9). Bitcoins are "the most important invention since the internet itself. They will change the way the entire world does business" (Ver in Popper, 2015, p 130). This is the "future universal currency, as science fiction had promised" (Popper, 2015, p 142); it "will change the entire world in a decade" (Popper, 2015, p 149); and "Bitcoin is the first time in five thousand years that we have something better than gold" (Popper, 2015, p 220). Finally, "[a] decentralised, anonymous, self-verifying and completely reliable register of this sort is the biggest potential change to the money system since the Medici. It's banking without banks, and money without money" (Lanchester, 2016, p 8) Taken at face value then, on the one hand, there is interesting potential to be explored in bitcoin and a challenge to established financial power. On the other hand, this might all be merely "myopic technological utopianism" (Golumbia, 2016, p 42) or a deliberate attempt to talk up a venture capital investment. ${ }^{10}$

Perhaps the apogee of bitcoin discourse is presented by ideologue Kelly (2015) in The Bitcoin Big Bang: How Alternative Currencies Are About to Change the World. Bitcoin discourse gains its evangelical zeal and its "euphoria stems from the realisation that Bitcoin could be the vehicle that transforms the financial system from centralised to decentralised" (Kelly, 2015, p 59) Kelly proclaims that, "[a] decentralised system is superior to the centralised system when preventing a failure at the hub is essential. There remains a risk that multiple hubs fail at the same time, but it is a step forward in the evolution of systems" (Kelly, 2015, p 67) This mirrors the discussion of decentralised networks instigated by Baran which I discuss further below. Instead of decentralisation being considered as based upon a geopolitical decision, being a contingent choice, serving a specific historical function, and with appropriate cost-analysis, it is claimed to be "superior," and indeed, a "step forward in the evolution of systems." The ideological process of universalising and naturalising that which is cultural and specific is achieved by positing decentralization as partaking in evolution and natural selection. The idea of technological change as quasi-autonomous, driven by some process of autopoiesis or self-organisation, "allows many aspects of contemporary social reality to be accepted as necessary, unalterable circumstances, akin to facts of nature" (Crary, 2014, p 36) In this way bitcoin and digital discourse "naturalizes, theologizes and teleologizes network technology" (Fisher, 2010, p 185). This discourse considers progress due to network technology as being a natural law and inevitable. Digital discourse thereby "neglects negative aspects of technology and society and provides a profoundly undialectical picture of the Internet and society" (Fisher, 2010, p 209) The consequence, for Fisher, is that digital discourse depoliticizes and neutralises the relation of 
technology and society. It is seen as something that the social should serve rather than serving the social.

There are examples of how, like other digital intermediaries, bitcoin enthusiasts must discursively frame their services and technologies as the march of progress, as superior, natural, and inevitable. They must also lay out a cultural imaginary within which their service makes sense (Wyatt, 2004). In the digital cultural imaginary, it is essentially compulsory that the individual be on-line, consuming, gambling, gaming, working, blogging, downloading, or texting 24/7: "since no moment, place, or situation now exists in which one can not shop, consume, or exploit networked resources, there is a relentless incursion of the non-time of 24/7 into every aspect of social or personal life" (Crary, 2014, p 30). Bitcoin, with its ethos of ultra-fast and smooth transactions, partakes of this $24 / 7$ instantaneous imaginary. The digital cultural imaginary both fosters and requires "nodal citizenship" and "nodal consumption." For Bolimer, "nodal citizenship" is Deleuzian control, and Foucauldian governmentality of the self. Digital culture is not simply just a set of technological platforms or devices, but normalises certain behaviours, and carries specifications for "the proper conduct one should internalise in a world defined by network technologies...in which the maintenance of connections and perpetuation of flows is the task of a good 'citizen,' especially as embodied by the materiality of network technology" (Bolimer, 2016, p 6). During Fordism, technology discourse and the cultural imaginary legitimated the interventionist welfare state, central planning in business and the economy, the hierarchized coroporation, and the tenured worker. However, during financialization and our contemporary, post-Fordist society, technological discourse and the cultural imaginary legitimates instead, "the withdrawal of the state from markets, the globalization of the economy, the dehierarchization and decentralization of business, and the flexibilization of production and the labour process" (Fisher, 2010, p 3).

Such a cultural imaginary is one in which centralization is deemed an impediment to the decentralised flow of neoliberal finance. All government, especially centralised government is deemed oppressive, all central banks are rotten, finance and consumption must face no temporal or spatial limit, and freedom is freedom to engage smoothly in markets and neoliberalism and not freedom from markets and neoliberalism. In such bitcoin discourse several tropes come together-libertarian tropes from Nakamoto such as no need to "trust" government or banks, techno-utopian tropes such as efficiency, speed, connectivity, and cyber-anarchist tropes such as freedom, decentralization, distribution, and anonymity. Bitcoin's social and cultural imaginary is one in which government and banks cannot ever be trusted, where digital technology is always empowering, and where decentralized individual anonymity is preferred to collective recognition of social identity. Any form of regulation, law, centralisation, organisation, and collectivity, is rendered politically problematic and invisible to this imaginary. Such notions are considered big government interference, the road to serfdom, and an obstacle to be overcome. The corporation, neoliberalism, the free market, and economic power however, apparently need no check on their own trustworthiness, centralisation, growth and consolidation.

As Gillespie has shown with the notion of "platform"11 regarding Facebook, a term such as "decentralised," (or "distributed," or "financial flow," or "trust") in bitcoin discourse can become a "discursive resting point" (Gillespie, 2010, p 350) that conceals and elides various tensions. Further innovations may be oriented towards that idea of how technology is to function in the social and cultural imaginary. Such terms "institute" a way of being: as Bourdieu puts it, they "sanction and sanctify a particular state of things, an established order, in exactly the same way that a constitution does in the legal and political sense of the term" (Bourdieu in Gillespie, 2010, p 350). In bringing together ideas of decentralisation, digital utopianism, and technological progress, right-wing libertarian ideology sets and shapes public discourse around digital currencies: "These terms and claims get further established, reified, and enforced as they are taken up and given legitimacy inside authoritative discourses such as law, policy, and jurisprudence" (Gillespie, 2010, p 356) This discourse maps onto recent enthusiasm for user-generated content, amateur expertise, popular creativity, peer-level social networking, and online commentary. Aside long-standing rhetoric about the alleged democratizing potential of the Internet, bitcoin rhetoric is like much digital discourse with connotations of "open, neutral, egalitarian, and progressive support for activity" that accompany the notion 'platform' as Gillespie has identified (Gillespie, 2010, p 353). This discourse functions to make the terms compelling for digital intermediaries to appeal to users, especially in contrast to traditional mass media or, in the case of bitcoin, traditional economic institutions. However, despite the promises made, "' 'platforms' are more like traditional media than they care to admit... And the discourse of the 'platform' works against us developing such precision, offering as it does a comforting sense of technical neutrality and progressive openness" (Gillespie, 2010, p 360) Likewise, as shall be argued, decentred financial networks function more like traditional financial powerhouses and operate in line with the power structures of centralized networks. There is no neat ideological fit between the digital dream of the decentralized, open, participatory web, and the digital reality. Within such fissures critique can operate. ${ }^{12}$

Bitcoin discourse and Nakamoto's white-paper collates into a series of presuppositions that I would like to begin to problematize. First, that decentralized networks and free-markets without regulation or government mediation are fully enabling and apolitical. I challenge this by emphasising the right-wing ideology inherent in bitcoin technology and discourse. Second, there is a valorisation of decentralisation that is in some sense a progression from centralisation. This notion forgets the architecture and origins of the internet. It also omits the threats to decentralisation such as the virus and hacking. Finally, there is a utopian sensibility around the network that does not consider the problems of networks. I suggest this is a form of networkfetishism. $^{13}$

\section{Bitcoin as right-wing ideology}

Much of the digital economy has right-wing origins whether these are made explicit or eschewed. At one stage, Uber's Travis Kalanick's Twitter account had the cover of Ayn Rand's manifesto The Fountainhead as its avatar (Stone, 2017, p 259). In terms of bitcoin, Golumbia (2016) presents the clearest vision of its ideology and politics, and what emerges is the notion of software as right-wing extremism: "As they are currently configured, Bitcoin and the blockchain technology on which it rests satisfy needs that make sense only in the context of right-wing politics" (Golumbia, 2016, p 20). The cyberpunks and crypto-anarchists, influential upon the development of bitcoin, seem to accept, often without even appearing to realise it, the far-right, libertarian/ anarcho-capitalist definition of government, such as, "Ronald Reagan's inaugural address of 1981, in which he famously claimed that 'government is not the solution to our problem; government is our problem" " (Golumbia, 2016, p 16) The zeal of the cyberlibertarians towards bitcoin, which might possibly evade government, regulation, and taxation, stems from a belief system that "links ecstatic enthusiasm for electronically mediated forms of living with radical, right-wing libertarian ideas about the proper definition of freedom, social life, economics and politics" 
(Golumbia, 2016, p 10) Hal Finney, for instance, who received the first bitcoin transaction from Satoshi Nakamoto, imbued "libertarian ideas at $\mathrm{Cal}$ Tech and in his reading of the novels of Ayn Rand" (Popper, 2015, p 23). Gavin Andresen, the lead maintainer for the original bitcoin client, "had moved toward libertarianism during his first programming job, swayed by a persistent coworker. These politics gave him a natural interest in a free-market currency like Bitcoin" (Popper, 2015, p 68). In proposing that bitcoin escapes the issue of inflation, much bitcoin discourse, "takes up the simplistic far-right version of [Milton] Friedman's contention that inflation is just another name for the "printing of money' by central banks" (Golumbia, 2016, p 28) In essence, bitcoin originated from, and is a common preoccupation of the libertarian pro-tech, radical right.

\section{Decentralization and its discontents}

Bitcoin is celebrated as utilising a decentred network in a way that purportedly challenges centralisation. Decentralized networks are deemed a natural progression over centralised networks. Such claims often ignore the historical architecture of the internet. Paul Baran is cited by Berners-Lee as one of three individuals responsible for the development of the "general communications infrastructure that links computers together, on top of which the Web rides" (Berners-Lee, 1999, p 6). Baran's (1962) "On Distributed Communication Networks" contributed to the "early research [that] would eventually develop into the internet" (Bolimer, 2016, p 99). Baran ${ }^{14}$ discusses three types of network: centralized, decentralized, and distributed. ${ }^{15}$ Communication in a centralized network is vulnerable, Baran suggests, because " $[\mathrm{d}]$ estruction of the central node destroys intercommunication between the end stations" (Baran, 1962, p 3). Preferable then, in this scenario, would be a decentralised network, "because complete reliance upon a single point is not always required" (Baran, 1962, p 3). Baran was writing, as he puts it, in the "thermonuclear era...that must anticipate a worst-case destruction" (Baran, 1962, $\mathrm{p}$ 18). The discussion of networks, informing what we now understand as the Internet, is founded on geopolitical antagonism $^{16}$ and the paranoia of nuclear war: "The network must be built with the expectation of heavy damage" (Baran, 1962, p 19). A decentralized network, with no central node that can be destroyed, will allow military communication to be maintained. This will allow the US to return nuclear fire ${ }^{17}$ and lead to mutually assured destruction. This confirms the often overlooked or unacknowledged, "relationship the internet's development has with fears of nuclear war" (Bolimer, 2016, p 99). Also factored into the development of the Internet by Baran is the cost-analysis of the capitalist middle-manager: "In choosing the communication links of the future, digital links appear increasingly attractive by permitting low cost switching and low cost links" (Baran, 1962, $\mathrm{p}$ 18). Baran's model negotiated the numerous contradictory historical attributes of networks to "invent a structure that was all-encompassing, restrictive, and potentially totalizing while simultaneously weak, fluid and flexible" (Bolimer, 2016, p 100). In summation, the creation of a cheap, and therefore weak network designed to maintain US military communication in the case of nuclear war has been adapted ${ }^{18}$ and adopted to influence the architecture of what we now know as the Internet. ${ }^{19}$

Whilst decentralization, in its response to a perceived threat, has facilitated certain elements of electronic communication it also opens a new problem: the computer virus. The possible threat to a centralized node may have been somewhat alleviated but this does not create security, instead the threat simply changes location. The decentralized multiple and weak nodes are now made vulnerable to viruses, worms, hacking, cyberterrorism, anomalies, accidents, assemblages, contagions, and so forth. The "solution" of decentralisation creates its own new problems and threats. The very nature of a decentralised network with multiple weak nodes and packet-switching produces the perfect environment for a virus to spread and hacking to occur. Packet-switching is a mode of data transmission in which a message is broken into a number of parts which are sent independently, over whatever route is optimum for each packet, and reassembled at the destination. This is championed in Baran's network, and introduces local intelligence to communications. Instead of being controlled from above from a centralised, hierarchical position, network communications decentralised control into small packets which find their own way from sender to recipient. The basic architecture of the Internet has been based on data that is intelligent in the sense that it contains its own instructions for moving, using networks to accomplish its operations: "In this sense, we can justifiably claim that the origins of worm-like-and partly viruslike-programs lie in the schematics of network computing in general" (Parikka, 2005). Viruses, hacking, and so forth, cannot be eliminated so long as the ontology of network culture is viral-like. The computer virus "thrives on the openness of info-space... thrives on the infinite potential of algorithmic computing; the open, flexible and undecidable grammar of the algorithm allows the virus to spread, infect and evolve" (Sampson, 2004). Decentralization has given birth to "the anarchic virus [which] is without a central agency; it is a profound rejection of all Generals and power centres" (Sampson, 2004). What was once proposed as a solution-of sorts-to the supposed problem of the centralization of networks has thrown up its own problems in terms of the virus and hacking. Bitcoin itself "is always one big hack away from total failure" (Popper, 2015, p 13). On 19 June 2011, when a bitcoin exchange platform was hacked-administrators had needed only a single password to log in ${ }^{20}$ - bitcoin fell in value from $\$ 17$ to 1 cent in less than an hour (Popper, 2015, p 129).

\section{Network fetishism}

Networks are often fetishised, presented and assumed to be decentred and democratic because they supposedly exist without central command. This is supposed to facilitate non-hegemonic, noncoercive, individualistic freedom of movement, while encouraging some kind of distributed representation and engagement. To this utopian vision we have become increasingly suspicious: "Don't we know now that networks also produce stoppages, closures, dark spots, and their own particular forms of control and governance?" (Aranda et al., 2015, p 7) Further possible problems, and the poverty, of decentred networks are outlined by Berry (2008). A new form of social organisation is developing in relation to the network and networks are celebrated as being "decentred, limitless and often, it is claimed, non-hierarchical and structureless forms or fluid organizations" (Berry, 2008, p 365). It follows that a distinction is made between two apparently antagonistic economic, social and technological forms: "industrial hierarchical mass production vs. peer-produced decentralized network production" (Berry, 2008, p 371). In this scheme a new priority is given to "ownership of the immaterial-software, algorithms, patents and copyrightthat will determine the shape of the new age" (Berry, 2008, p 370). It is here, however, that Berry argues that we see the emergence of a problematic binary-material/immaterial—and that even "something as ephemeral as software has a concrete materiality which problematizes this distinction" (Berry, 2008, p 370). It is the case that the amount of power consumed by blockchain operations is so large that it has been suggested that bitcoin itself is "unsustainable" (Malmo in Golumbia, 2016, $\mathrm{p}$ 43). The materiality of the network, and the exploitative 
relations inherent in such materiality, are a blind-spot in network fetishism.

Trouble continues when we forget that the network models and diagrams we use are generative of a real yet to come, ${ }^{21}$ when we think that the world conforms to our digital models and algorithms ${ }^{22}$, or when, "we attempt to remake the world in terms of our network theories" (Berry, 2008, p 365). These models are simplifications of the world: "The network is not ontological it is analytical, and as such it is restricted in how much it can tell us and how useful it can be" (Berry, 2008, p 365). The problem is that "the existence of networks invites us to think in a manner that is appropriate to networks" (Berry, 2008, p 366). Networks privilege the connected, as the unconnected-by definition-are not within the network. They distort a reading of reality that highlights synchronic dispersal over diachronic unfolding. In this sense, networks "abolish history and shift our focus to the event, the happening or the now" (Berry, 2008, p 366). The idea of the decentred network remains only "a spatial diagram which provides topological information about the nodes that are connected with it" (Berry, 2008, p 371). Crucially, "it flattens reality and removes the distinctions between different nodes" (Berry, 2008, p 371). This means that in a network "an individual programmer and a multinational corporation become equal as connected nodes in the network" (Berry, 2008, p 371). What looks equal, democratic, and decentred in the diagram of the network, with simple links and lines of connectivity between indistinguishable nodes, conceals a massive distortion of power and power relations. Here we might make a distinction between the network and the node in the way that Bruno Latour, in philosophical discussion with Peter Sloterdijk, makes a distinction between the network and the sphere. ${ }^{23}$ Unlike networks, "spheres are not anemic, not just points and links, but complex ecosystems" (Latour, 2015, p 41). Likewise, nodes must be considered as complex ecosystems behind the apparent simplicity of points, links, and lines of diagrammatic representation. Decentralized network fetishism conceals relations and systems of domination, exploitation, and alienation. This is arguably what has happened with bitcoin. There is an illusion of circumventing economic power with decentralised nodes but what has emerged upon closer scrutiny is the corporate occupation of cyberspace in powerful and deep nodes.

\section{Another bitcoin obituary}

In its first few years, bitcoin was a digital cottage industry run by hobbyists and "the technology was still essentially just a volunteer project that relied on the goodwill of users" (Popper, 2015, p 67). Bitcoin could be mined by relatively fast home computers acting as relatively equal nodes in a decentralised network. Today, however, most successful mining is done by pools of dedicated high-power systems in a sign of increasing nodal power and capital colonisation of the internet. It is this nodal power that network fetishism is blind to. As Golumbia suggests, this fact alone "has raised significant questions about Bitcoins claim to 'democratise' or 'decentralise' currency operations" (Golumbia, 2016, p 43). This also makes the Bitcoin system exposed to the '51 percent problem': if one node or cluster of nodes owns more than 51 percent of the mining operations it could, at least theoretically, "change the rules of Bitcoin at any time" (Golumbia, 2016, p 43). There are also debates ${ }^{24}$ around bitcoin "forks"-in open source software development terms, a possible shift to a new version. These problems indicate that bitcoin is not as decentralised as it imagines: "Bitcoin's own governance structures displayed exactly the autocracy, infighting, bad faith, and centralisation that the blockchain is often said to have magically dissolved" (Golumbia, 2016, p 101) In essence, the promise of decentralisation has not been kept and network fetishism has concealed the fact that certain nodes function as centralised power bases.

Has bitcoin succeeded, or hinted at potential, in becoming digital money? At a most basic level, money ${ }^{25}$ is typically held by economists to have three prime functions: it serves as an accounting unit, it has exchange-value (it serves as a medium of exchange), and it has a use-value (it can store wealth). Bitcoin is arguably so well-known because of its volatility-its price has fluctuated wildly, and it is open to derivation and speculation. ${ }^{26}$ There is, at present, no stability, which makes it hard to consider bitcoin a secure store of value in the way that modulated gold might store value, or even the way that fiat money (regulated by the state), which bitcoin was promoted to replace, might store wealth. Bitcoin's very lack of regulation, and openness to the whim of the market-again, something that was championedensures a volatility that prevents the stability necessary to store wealth or, indeed, act as a unit of account. The fact that bitcoin largely "floats free of any anchor to ordinary valuing processes" (Golumbia, 2016, p 71). means that it cannot fully function as a stable accounting unit. ${ }^{27}$ In 2014 Goldman-Sachs announced that "Our best definition would be that it is currently a speculative financial asset that can be used as a medium of exchange" ${ }^{28}$ Most accounts of Bitcoin, such as Brian Kelly's The Bitcoin Big Bang, ignore the other functions of money and reduce money to currency only. Early on, the pseudonymous nature of Bitcoin made it the currency of choice for illegal activity on Silk Road, a dark web vending site, using the anonymity software Tor. This may well be its legacy: for a short time facilitating illegal activity and the dissemination of drugs, weapons, and dubious pornography. It is as a speculative financial asset that the volatility of bitcoin can be understood. Like any Ponzi scheme, the investment must be constantly talked-up, the bubble inflated, and this allows understanding of much of the hyperbole of bitcoin discourse.

There has been hope in some quarters that bitcoin as digital money, peer-to-peer, with encryption, would be taken up and replace, or compete, with the likes of PayPal. However, this has not been the case. On the horizon for bitcoin is the attempt by the likes of Apple, Google, and Facebook to become payment platforms. They will, like bitcoin, collect a small fee for transactions, but they will also, crucially unlike bitcoin, obtain the data that goes along with the transaction. Data is the new "kind of raw material" (Srnicek, 2017, p 38) of the digital economy that is being extracted and exploited. The current strong position these household name platforms have, as well as the business model of extracting more data, will see one or more of them attract enough investment and venture capital to fund a "growth before profits" model (Srnicek, 2017, p 20). This will raise use and activity, and eventually begin to monopolise the actions and transactions of the digital economy. In this proposed scenario, and with competition from other digital monies such as Ethereum, Dogecoin, and Litecoin - which purport to improve upon bitcoin's inefficiencies-bitcoin is likely to be unable to compete. There may well be a bursting of the bitcoin bubble, or long drawn out deflation, and all that will be remembered is likely to be an early innovative experiment in cryptocurrency.

The bitcoin obituary is almost a genre of its own. ${ }^{29}$ In response to the failure of bitcoin, at least in terms of its own original ambition, new Silicon Valley advocates began arguing in 2014 that the significant technological development was not, as Nakamoto initially intended, a network that allowed participants to make anonymous transactions outside the reach of the government and banking system, but rather digital cryptology and distributed ledger technologies. It is ironic that centralised governments and banks are now taking opportunity of this digital technology to increase their control and power in a way that goes against the ethos of early bitcoin ideology. In 2016, the UK 
government's chief scientific adviser issued a report which said that distributed ledger technologies "have the potential to help governments to collect taxes, deliver benefits, issue passports, record land registries, assure the supply chain of goods and generally ensure the integrity of government records and services" (Lanchester, 2016, p 11). It is thought that the blockchain can be adapted to do this with lower friction, lower cost, and higher security than any existing system. The use of the blockchain, albeit not in its original bitcoin form, has naturally attracted the attention of the banks. Financial institutions, whose centralisation bitcoin was originally intended to subvert, are going to use this new technology to maintain their power and keep themselves right where they are: "in the middle of every possible transaction network, extracting all the rent they can" (Lanchester, 2016, p 12). Far from weakening government, the banks, and transforming business, the irony and cautionary tale of bitcoin is that these enterprises are likely to be empowered by the digital technology that bitcoin inaugurated. In terms of wider social implications, DuPont has argued that cryptography is a new weapon in the Deleuzian control society: "controlling economics through the ordering application of Bitcoin" (DuPont, 2014). The digital economy has not seen the end of ownership and power but rather the concentration of property and power. In the future, one might have to modify Marx and Engels' famous slogan somewhat: "Decentred digital networkers of the world, unite! You have nothing to lose but your blockchains!"

\section{Conclusion, bitcoin, the commons, and collectivization}

Can bitcoin and its technology have a more progressive future? One such claim is made In The Real World of the Decentralized Autonomous Society, where Garrod (2016) investigates the notion, celebrated by its enthusiasts, that bitcoin represents the coming of a decentralized autonomous society in which humans are free from centralised forms of power and control. Garrod is rightly critical of certain elements of this notion insofar as "freedom" and autonomy here is conceived of as only "freedom" and autonomy from the supposed tyranny of the state, not 'freedom' from, for instance, the tyranny of the market. Bitcoin discourse, "neglects the power that capital holds over us" (Garrod, 2016, p 62) Despite this criticism Garrod proposes that something can be saved from the bitcoin experiment in digital decentralization and utilised on the Left or for the Commons. Based on the model of bitcoin technology, it may be "possible to create distributed collaborative organizations or 'open co-operativism'" (Garrod, 2016, p 73). This could be used to help smaller, regional areas protect their own commons-whether they be in the form of healthcare, education, water, air, Internet, knowledge, and so on. In Garrod's scenario, there is the possibility of harnessing reactionary technology for progressive aims, that is, taking bitcoin and its technology outside of its neoliberal emergence and context to forward the aims of the Left and serve the Commons. ${ }^{30}$ With appropriate caution, Garrod claims that bitcoin can "provide the basis for progressive human development" (Garrod, 2016, p 74).

It is agreeable that one must challenge oppressive structures and technological practices, but what if one is employing the technology and tools of the oppressor, ${ }^{31}$ and that these tools transform and distort the holder in their application? ${ }^{32}$ Has a technology that was developed to serve the interests of the political right ever been successfully recuperated by the left? ${ }^{33}$ At least these are concerns worth raising. The discourse around utilization of digital cryptology appears to be dominated by issues surrounding the protection of wealth and security of private property -is this compatible with the aims of the Left and the Commons? Perhaps the biggest obstacle to the progressive possibilities of bitcoin technology is that bitcoin digital decentralisation is a thoroughly ideological and neoliberal notion, both in terms of its infrastructure and as a product of technology. As Golumbia has it, "political values are very literally coded into the [bitcoin] software itself" (Golumbia, 2016, p 102). If there is to be a progressive employment of this digital technology, then this code and software will need much reconsideration.

Ultimately it may only be the humanization ${ }^{34}$ and collectivization of the Internet that sees true progressive values being met. "Perhaps today we must collectivise the platforms," suggests Srnicek (2017, p 127) and Golumbia argues that what is required to combat power "is not more wars between algorithmic platforms and individuals who see themselves as above politics, but a reassertion of the political power that the blockchain is specifically constructed to dismantle" (Golumbia, 2016, p 102). A reaffirmation and resurgence of organised assembly, public controlled and collective power to govern and regulate certain elements of the digital economy could lead to the breaking up of digital monopolies, regulate business practices, ban exploitative "lean platform" employment conditions, impose new privacy controls, coordinate action on tax avoidance, liberate us from the tyranny of markets, and begin to place capital and power into public hands. Long-term egalitarian goals and progressive political objectives can come from the collective, rather than a designated centralised figurehead. All the while monitoring and mitigating the worst excesses of State power, and being independent of the "surveillance state apparatus" (Srnicek, 2017, p 127). This is ambitious of course, but would see the true progressive potential of the Internet finally in sight.

Received: 20 August 2017 Accepted: 15 January 2018

Published online: 13 February 2018

\section{Notes}

1 The word bitcoin is a compound of bit and coin. While some sources capitalise bitcoin to distinguish between bitcoin as a technology and network and bitcoin as a unit of account, the OED advocates use of lowercase in all cases.

2 In typical cyber-utopian discourse, Stone (2017) proposes that digital technological giants such as Uber and Airbnb and the broad business model that is being replicated - "Uberification"- are "changing the world", are the "new architects of the 21st century", and yield as much power as the world's political leaders. These fledgling Silicon Valley start-ups have risen to global dominance, largely by being sustained by venture capital, circumnavigating — disrupting—established legal requirements, and ironically by (ab)using popular support to overcome regulators and "outdated" laws. The branding of Uber as "effortless" and "seamless" has persuaded people that private transport is preferable to public transport, and Airbnb through the marketing of "connectivity" and "community" have promoted private ownership and private collection of rent over social housing. The capitalist-consumer replaces the citizen is now an entrepreneur of their own capital, space, and time. Peer-to-peer networking has undoubtedly transformed the holiday rental and taxi markets for many people worldwide, and will further transform it once monopoly status is attained. For all their ultra-modern ethos and purported mastery of data and technology there remains a harsh, classic capitalist, business-as-usual procedure behind the scenes of this growth. Uber's Travis Kalanick, for a time, Donald Trump's Strategic and Policy Forum corporate adviser, is portrayed by Stone as openly aggressive, disdainfully turning his chair to face away in a regulation meeting, suggests his rivals are likely to fail by becoming "doomed by civility", and "chronic niceness". Ethics and idealism, in the digital economy, are cited as being "deadly" flaws in e-business (Stone, 2017). In attempting to bypass regulations Airbnb and Uber have been accused of failing to alert hosts and drivers to their legal responsibilities, facilitate the precarious "gigeconomy", provide no employment rights and remedies, and both are "tax-skimmers" making profits by dodging rules, taxes, and licensing fees that apply to their traditional rivals. It is claimed that once basic worker rights are given to employees that these are economically unsustainable businesses (Srnicek, 2017, p 118). They remain propped up and afloat due to short-term venture capital investment which seeks a long-term return once monopoly conditions are attained. In this global digital economy, much of the West's apparent affluence comes from outsourcing and exploitation of the "third-world". In considering practises such as cobalt mining in Congo and the Foxconn / Apple sweatshops in China, Qiu (2016) persuasively 
introduces the notion of the iSlave and proposes parallels between the digital economy and Atlantic slavery. The comparison between Uber and bitcoin can only go so far. It is accepted that Uber is not a peer to peer matching system for unused capacity of cars and passengers trying to get from A to B, but rather a quite centralized and powerful platform orchestrated by a company with designs on monopoly and the displacement of its network of drivers by autonomous vehicles.

3 Tim Berners-Lee, so-called inventor of the World Wide Web, wrote in 1999, "We certainly need a structure that will avoid those two catastrophes: the global uniform McDonald's monoculture, and the isolated Heaven's Gate cults that understand only themselves." (Berners-Lee, 1999, p 203) Unfortunately, Berners-Lee ambiition has not been met. Given the corporate colonisation of the internet on the one hand and the inevitable end of "net neutrality," and the emergence of the "alt right" and dissemination of "fake news" on the other, both catastrophes have occurred. The decentred nature of the Internet has meant no centralised resistance, such as the State, to the corporation and no centralised pedagogic or moral resistance to the "alt right" or duplicitous content.

4 Satoshi Nakamoto is the pseudonym of the individual or collective responsible for the initial design and development of bitcoin, and who disseminated the "white paper" Bitcoin: A Peer-to-Peer Electronic Cash System (Nakamoto, 2008). Bitcoin, itself, is pseudonymous. It is not anonymous since every transaction is recorded, "but determining the true identities of those involved in the transactions requires more information than is directly available in the network" (Golumbia, 2016, p 39).

5 Zimmer explores both the metaphor and literalism of the notion of bitcoin mining, making connection with previous metalist currency regimes. Zimmer proposes a historical comparison with colonial South American silver mining and the global currency regime based on the New World silver peso it created. Zimmer foregrounds an historical and political understanding of bitcoin's stakes, including questions of resources, labour, energy, and ecology. Traditional mining and the attendant extractive apparatus always implies massive-scale earthworks that reshape the planet itself, a process known as terraforming. Zimmer concludes that this comparison reveals bitcoin to form part of a similar process of digital primitive accumulation that he provisionally names cryptoforming. In the process Zimmer shows how, despite all the talk of decentralization, bitcoin is reproducing the pattern of mining in general, which is towards centralisation, as witnessed in the bitcoin mining consolidation of the recent past.

6 However, with the full record of transactions on the blockchain, "it was often possible to identify the people involved in transactions, or at least more possible that it was with transactions involving cash" (Popper, 2015, p 343).

7 Financialisation signals the transition from the Fordist mode of production to financial capitalism and the attempt to recover what capital could no longer get in the real economy in financial markets. (Marazzi, 2011) In the 1950s financial concerns made up $4 \%$ of total corporate profits by 2006 this had increased to account for $40 \%$ of such profits, intensified by developments in digital technology. In the 1970s and 1980s, nonfinancial firms increased their investment in financial assets relative to that in plants and equipment. In a subversion of the Fordist norm, they became increasingly dependent on immaterial financial sources of revenue and profit relative to that earned from productive activities. The implications of this immaterial hyperreal economy free from the real material economy, is the autonomisation of financial capital from real interests such as land, machinery, labour, and stock. Investment in production is no longer attractively profitable, so capital is redirected to financial markets where a stronger return is promised: this is stock managerial capitalism. This intensified in the under-regulated, under scrutised, distribution of sub-prime loans, and derivatives based on these loans, which when they could not be paid back, resulted in a crash.

8 http://www.righto.com/2014/02/ascii-bernanke-wikileaks-photographs.html [Accessed 1 April 2017]

9 Maurer et al. consider that bitcoin represents a promise like any other money form, "but a promise underwritten and backed by an algorithm and its manifestation in a digital peer-to-peer network" (Maurer et al., 2013, p 274). Despite what they call the "practical materialism" of bitcoin, Maurer et al, indicate that the "social dynamics of community and trust" are still evident in "the prose and poetry produced by Bitcoin users" (Maurer et al., 2013, p 262). They remind that, certainly in the early days, bitcoin combined "a practical materialism with a politics of community and trust that puts the code front and center" (Maurer et al., 2013, p 63). For them, this is a trust in the code that "substitutes for the (socially and politically constituted) credibility of persons, institutions, and governments. It is this-not the anonymity or the cryptography or the economics- that makes Bitcoin novel in the long conversation about the nature of money" (Maurer et al., 2013, p 263). Ultimately, in early bitcoin, "trust in the code does not erase entirely the community that bestows it" (Maurer et al., 2013, p 274). Whether one can talk of such a community nowadays is debatable.

10 During the dot-com bubble the average size of venture capital deals quadrupled between 1996 and 2000 when investors sought future profitability in adopting a "growth before profits" model. This model seeks "to grab market share and eventually dominate...aiming for monopolistic dominance" (Srnicek, 2017, p 20) More recently, technology companies have been particularly keen to make venture capital investment. These companies only need to move intellectual property rather that materials like factories to different tax jurisdictions to facilitate tax evasion. Therefore, they have been left "with a vast amount of money to invest" (Srnicek, 2017, p 32).

11 'The term 'platform' helps reveal how YouTube and others stage themselves for these constituencies, allowing them to make a broadly progressive sales pitch while also eliding the tensions inherent in their service: between user-generated and commercially produced content, between cultivating community and serving up advertising, between intervening in the delivery of content and remaining neutral" (Gillespie, 2010, p 350).

12 My approach here is informed by Critical Internet Theory/Studies. Elmer (2002) proposed three characteristics of Critical Internet Studies: the refutation and questioning of ideologies that claim the Internet is revolutionary, the analysis of the process of Internet corporatisation, and the focus on radical possibilities of the critical Internet community especially in the cracks, fissures, and holes in the forms of domination that characterise the Internet. Following on from this, Fuchs defines Critical Internet Theory/Studies and the Critique of the Political Economy of the Internet as an approach that engages in "identifying and analysing antagonisms in the relationship of the Internet and society; it shows how the Internet is shaped and shapes the colliding forces of competition and cooperation; it is oriented towards showing how domination and exploitation are structured and structuring the Internet and on how class formation and potential class struggles are technologically mediated; it identifies Internet-supported, not yet realized potentials of societal development and radically questions structures that restrain human and societal potentials for cooperation, self-determination, participation, happiness and selfmanagement" (Fuchs, 2009, p 75).

13 That is, an application and myopic understanding of the decentralised network without taking into account its historical formation and architecture, its politics (on both a local and global level), underlying ideologies, and problematic mode of production. Further, it is a view which accepts fully utopian notions of the entwining of technology and progress. It is argued that bitcoin is vulnerable to such an approach. As in the classic study of commodity fetishism, bitcoin pioneers promoted the decentralised network's appearance as an autonomous figure endowed with a life of its own. In this case, the network functioned as a mask that conceals economic, and other, exploitation.

14 It can be suggested that Baran anticipates the Internet(work) in passages such as, "we would like to consider the interconnection, 1 day, of many all-digital links to provide a resource optimized for the handling of data for many potential intermittent usersa new common-user system" (Baran, 1962 p 23).

15 Decentralized and distributed networks are often conflated to stand in opposition to centralized networks in discussions of bitcoin.

16 One might mention here the work of Friedrich Hayek — a foundational source for the right and neoliberalism. His attack on any form of centralised government (particularly one involved in regulation and central planning, such as the Soviet Union) and political promotion of decentralisation (deregulated market competition) was likewise informed by fears-illusory or not—of a Soviet threat. One argument Hayek proposed was that in centrally planned economies an individual or a select group must determine the distribution of resources. However, argues Hayek, these planners will never have enough information to carry out this allocation reliably. For Hayek only the free market, through the price mechanism, can efficiently maintain exchange and the use of resources. Today, it can be counter-argued that, in principle, digital technology and data afford better centralised analysis of exchange and distribution of resources than the decentred market alone could possibly offer.

17 The decentred network influenced U.S. nuclear military design. As Schlosser explains, nuclear silos could be dispersed "widely throughout the Great Plains, so that a surprise attack by the Soviet Union couldn't easily destroy them all. In Montana, the new launch sites were built in an area extending for 14,000 square miles" (Schlosser, 2015, p 30). Crucially, however, the decentred network might alleviate one concernvulnerability of a central node-but in turn creates a new vulnerability of decentralised multiple and weak nodes. Schlosser insightfully adds that, "Decisions made for reasons of efficiency and military strategy in the twentieth century couldn't anticipate the implications for nuclear terrorism in the twenty-first" (Schlosser, 2015, p 31). For instance, Pakistan "has the world's fastest-growing nuclear arsenal. It has dispersed nuclear weapons to multiple locations, making them less vulnerable to destruction by a foreign nation but more vulnerable to theft by terrorists" (Schlosser, 2015, p 74). The network is also necessarily vulnerable to leaks, hacking, and so forth. Edward Snowden gained access to the classified secrets of the National Security Agency: "The NSA is responsible not only for generating the launch codes for America's nuclear-weapons but also for designing the equipment that decrypts the codes" (Schlosser, 2015, p 50).

18 Strengthening the historical connection between technology and antagonistic geopolitics, "the early 1990s saw the dissolution of the Soviet Union, and it is no coincidence that information networks in the United States were transitioned from a military to an economic function at the same time" (Aranda et al, 2015, p 6).

19 This follows the ideas forwarded by thinkers such as Friedrich Kittler and Paul Virilio, that the contemporary cultural condition is an essential coupling of war and media, and the cybernetic logistics of command, control, communications and intelligence. Strictly military networks extend to, and influence, the business and entertainment media. 
20 Similar low-fi security was apparent in July 2011, when the founder of a small Polish bitcoin exchange, Bitomat, announced he had "accidentally deleted the files where he kept the private keys to the Bitcoin addresses at which his customers' 17,000 Bitcoin were stored" (Popper, 2015, p 135).

21 "Dispositional expressions and active forms can be spatial softwares, protocols, or diagrams. A diagram, as Deleuze and Guattari render the idea, is not a representational sketch of a single arrangement but rather an 'abstract machine' that is generative of a 'real that is yet to come'" (Easterling, 2015, p 37).

22 Mullarkey discusses how Bergson famously scorned the diagrammatic image of a time as a time-line in a spatialisation of duration. It was threatening "precisely because lived-time can approach the state of a homogeneous line: we can tend to live unilinear pyschic-lives. This is the rationalisation behind Time and Free Will-that a description of life could become a revision of life because descriptions are immanent to what they describe" (Mullarkey, 2006, p 189).

23 Latour notes that the word "network" has become a ubiquitous designation for technical infrastructures, social relations, geopolitics, mafias, and, of course, our new life online: "while networks are good at describing long-distance and unexpected connections starting from local points, [Sloterdijk's] spheres are useful for describing local, fragile, and complex 'atmospheric conditions'... Networks are good at stressing edges and movements; spheres at highlighting envelopes and wombs" (Latour 2015, p 41). Instead of having to choose between Latour's actor-network theory and Sloterdijk's spherology, Latour announces the notion of what he calls 'composition' as an ambition to "regroup in one term those many bubbles, spheres, [and] networks" (Latour 2015, p 52)

24 While in principle, anyone could propose changes to the bitcoin protocol, Nakamoto and a colleague, "were still essentially the only people who could sign off on changes —and this gave them an unusual amount of power in the system" (Popper 2015, p 92).

25 As Dodd advises, money is a remarkably diverse phenomenon, "there is no common view of what counts as money in a general sense. There never has been a consensus about this: the extant literature on money is replete with debates over competing definitions" (Dodd, 2014, p 5) Following Keynes, there is debate over money's abstract role as money of account versus its properties as a medium of exchange. For his part, Dodd considers money as a social form. For example, the universal commodity form (Marx), a claim upon society (Simmel), diffuse social media (Zelizer), a social technology (Ingram), an instrument of collective memory (Hart), a generalised symbolic medium (Parsons), a social process of commensuration (Maurer), and a communal illusion (Karatani) (Dodd, 2014, p 8) One must consider if bitcoin can be considered in terms of a social form. Dodd proposes that money is best thought of as "an idea" (Dodd, 2014, p 48) Nakamoto's use of the term "cash" in the title of the white paper is evidence of this confusion over definitions and practices of money. Nakamoto is predominantly, in the white paper, outlining a currency.

26 Prominent bitcoin advocate Rick Falkvinge, who once claimed that the price of one bitcoin could eventually be as high as US\$1 million, later wrote in September 2013, that its valuation had become "unwarranted by several orders of magnitude" due to "illegal price-fixing," even though "for many Bitcoin enthusiasts, the Bitcoin market's unenforceability of government rules is a feature, not a bug" and that in manipulating the market, some bitcoin traders were engaging in "cheating of some kind, a breaking of the social contract" (Falkvinge in Golumbia, 2016, p 86). This makes dubious the bitcoin trust in the digital.

27 Dallyn utilises the conception of market singularities to understand bitcoin's status as a volatile financial asset. Market singularities are markets for particular goods and services that are of uncertain and incommensurable value. These singularities markets have communities of followers and a distinctive belief system. There is confirmation of the libertarian political belief system that underlies bitcoin's status but this is not fully unified and there are some political tensions within the community concerning governance and centralisation.

28 https://techcrunch.com/2014/03/12/goldman-sachs-BitCoin-is-not-a-currency/ [Accessed 1 April 2017]

29 There is also the sense that every sentence that begins to be written about bitcoin is superseded by events before it is even finished. DigiCash, created by cryptographer David Chaum by 1990, utilising "Blind Signature Technology," went bankrupt in 1998. Beenz.com (1998) and Flooz.com (1999), using a virtual cryptocurrency to assist with consumption, went bust in the 2001 dot-com crash. Bitcoin appears more durable at present. Over 900 cryptocurrencies have been launched since bitcoin.

30 This ambition is also outlined by Steveri: "If images can be shared and circulated, why can't everything else be too? If data moves across screens, so can its material incarnations move across shop windows and other enclosures. If copyright can be dodged and called into question, why can't private property? If one can share a restaurant dish JPEG on Facebook, why not the real meal? Why not apply fair use to space, parks, and swimming pools? Why only claim open access to JSTOR and not MIT-or any school, hospital, or university for that matter? Why shouldn't data clouds discharge as storming supermarkets? Why not open-source water, energy, and Dom Perignon champagne?" (Steyeri 2015, p 22).

31 There is frequent assertion that contemporary technological arrangements are essentially a neutral set of tools that can be used in many different ways, including in the service of an emancipatory politics. However, Crary utilises Giorgio Agamben to refute such claims: "today there is not even a single instant in which the life of individuals is not modelled, contaminated or controlled by some apparatus... [Therefore] it is impossible for the subject of an apparatus to use it in the right way. Those who continue to promote similar arguments are, for their part, the product of the media apparatus in which they are captured" (Agamben in Crary 2014, p 46).

32 Hoofd (2012) explores an analogous situation whereby digital activism-or the employment of digital technology-replicates the valorisation of speed, connectivity, and digital activity of the subject-agent of digital neoliberalism. This may actually have the outcome of accelerating and strengthening the spin of the digital neoliberal globe. Political activism means creatively using available tools and material resources, but it should not entail imagining the tools themselves to have intrinsic redemptive values.

33 This is the type of critical question, answered with silence, posed by Golumbia in response to the enthusiasm for bitcoin among those with explicitly left-wing politics "My response is to ask two questions analytically prior to this one: first, to ask for accounts of where and how it happened that a technology developed specifically to magnify the powers favoured by the political right has mutated so as not to serve those powers but the forces they oppose; and second, to ask for accounts on economic and political-economic grounds that proceed from left-wing thought (whether Marxian or Keynesian) to the need for and utility of Bitcoin" (Golumbia 2016, p 20).

34 "A humanization of the Internet requires a communist Internet in a communist society, an Internet that is not controlled by the logic of capital and by private profit making, but an Internet that is controlled by all users, benefits all users and is grounded in the logic of the information gift that is inexhaustible by consumption and accessible to all without payments, the logic of common access to technology and knowledge, common production, common ownership, common control, common interests beyond class, common benefits-the logic of the commons = the reality of communism" (Fuchs and Sevignani 2013, p 269).

\section{References}

Aranda J et al. (2015) Introduction. In: Aranda J, Wood BK, Vidokle A (eds) The Internet does not exist-e-flux journal, Sternberg Press, Berlin, pp 5-9

Baldwin J (2013) The financial crash and hyper-real economy. Thought Catalog, New York

Baran P (1962) On distributed communication networks. http://pages.cs.wisc.edu/ akella/CS740/F08/740-Papers/Bar64.pdf. Accessed 17 April 2017

Barber A (2015) Bitcoin and the philosophy of money: evaluating the commodity status of digital currencies. Spectra 4(2). https://spectrajournal.org/ SPECTRA/article/view/241/169. Accessed 18 Sept 2016

Berners-Lee T (1999) Weaving the web-The original design and ultimate destiny of the world wide web by its inventor. Harper, San Francisco

Berry D (2008) The problem of networks. Theory Cult Soc 25(7-8):364-372

Bolimer G (2016) Inhuman networks: social media and the archaeology of connection. Bloomsbury, New York

Crary J (2014) 24/7 Late capitalism and the ends of sleep. Verso, London and New York

Dallyn S (2017) Cryptocurrencies as market singularities: the strange case of bitcoin. J Cult Econ 10(5):462-473

Dodd N (2014) The social life of money. Princeton University Press, Princeton, NJ DuPont Q (2014) The politics of cryptography: bitcoin and the ordering machines. J Peer Prod 4. http://peerproduction.net/issues/issue-4-value-and-currency/ peer-reviewed-articles/the-politics-of-cryptography-bitcoin-and-theordering-machines/. Accessed 18 June 2017

Easterling K (2015) An Internet of things. In: Aranda J, Wood BK, Vidokle A (eds) The Internet does not exist-e-flux Journal, Sternberg Press, Berlin, pp 27-39

Elmer G (2002) Critical perspectives on the Internet. Rowman \& Littlefield, Lanham

Fisher E (2010) Media and new capitalism in the digital age-The spirit of networks. Palgrave Macmillan, New York

Fuchs C (2009) Information and communication technologies and society. A contribution to the critique of the political economy of the Internet. Eur Commun 24(1):69-87

Fuchs C, Sevignani S (2013) What Is digital labour? What Is digital work? What's their difference? And why do these questions matter for understanding social media? tripleC: Commun Capital Crit 11(2):237-292

Garrod JZ (2016) The real world of the decentralized autonomous society. tripleC: Commun Capital Crit 14(1):62-77

Gillespie T (2010) The politics of "platforms" New Media Soc 12(3):347-364

Golumbia D (2016) The politics of bitcoin-Software as right-wing extremism. University of Minnesota Press, Minneapolis

Goux J (1994) The coiners of language. University of Oklahoma Press, Norman, $\mathrm{OK}$

Hoofd I (2012) Ambiguities of activism: alter-globalism and the imperatives of speed. Routledge, London and New York

Kelly B (2015) The bitcoin big bang: how alternative currencies are about to change the world. Wiley, New Jersey

Lanchester J (2016) When bitcoin grows up. Lond Rev Books 38(8):3-12 
Latour B (2015) Some experiments in art and politics. In: Aranda J, Wood BK, Vidokle A (eds) The Internet does not exist-e-flux Journal, Sternberg Press, Berlin, pp 40-53

Marazzi C (2011) The violence of financial capitalism. Semiotext(e), New York

Maurer B, Taylor CNelms, Swartz Lana (2013) When perhaps the real problem is money itself!: the practical materiality of bitcoin. Soc Semiot 23(2):261-277

Mullarkey J (2006) Post-continental philosophy-an outline. Continuum, London and New York

Nakamoto S (2008) Bitcoin: a peer-to-peer electronic cash system. Bitcoin.org. https://bitcoin.org/bitcoin.pdf. Accessed 17 April 2017

Nakamoto S (2009) Bitcoin open source implementation of P2Pcurrency. http:// p2pfoundation.ning.com/forum/topics/bitcoin-open-source. Accessed 11 May 2017

Parikka J (2005) The universal viral machine-bits, parasites and the media ecology of network culture. CTheory 15(12). https://journals.uvic.ca/index. $\mathrm{php} /$ ctheory/article/view/14467/5309. Accessed 5 May 2017

Piketty T (2014) Capital in the twenty-first century. Belknap Press, Cambridge, MA

Popper N (2015) Digital gold-bitcoin and the inside story of the misfits and millionaires trying to reinvent money. Harper, New York

Qiu JL (2016) Goodbye iSlave-a manifesto for digital abolition. University of Illinois Press, Urbana, IL

Sampson T (2004) A virus in info-space. M/C J 7(3). http://journal.media-culture. org.au/0406/07_Sampson.php. Accessed 14 Feb 2017

Schinckus C (2008) The financial simulacrum. The consequences of the symbolic and technological virtualization of the financial market. J Socio-Econ 37 (3):1078-1095

Schlosser E (2015) Gods of metal. Penguin Books, Harmondsworth

Srnicek N (2017) Platform capitalism. Polity Press, Cambridge

Steyeri H (2015) Too much world: is the internet dead? In: Aranda J, Wood BK, Vidokle A (eds) The Internet does not exist-e-flux journal, Sternberg Press, Berlin, pp 10-26

Stone B (2017) The upstarts: how Uber, Airbnb, and the killer companies of the new silicon valley are changing the world. Bantam Press, London

Wyatt S (2004) Danger! Metaphors at work in economics, geophysiology, and the Internet. Sci Technol Human Values 29(2):242-261
Zimmer Z (2017) Bitcoin and potosí silver: historical perspectives on cryptocurrency. Technol Cult 58(2):307-334

\section{Data availability}

Data sharing is not applicable to this paper as no datasets were generated or analysed.

\section{Additional information}

Competing interests: The author declares no competing financial interests.

Reprints and permission information is available online at http://www.nature.com/ reprints

Publisher's note: Springer Nature remains neutral with regard to jurisdictional claims in published maps and institutional affiliations.

\section{(c) (i)}

Open Access This article is licensed under a Creative Commons Attribution 4.0 International License, which permits use, sharing, adaptation, distribution and reproduction in any medium or format, as long as you give appropriate credit to the original author(s) and the source, provide a link to the Creative Commons license, and indicate if changes were made. The images or other third party material in this article are included in the article's Creative Commons license, unless indicated otherwise in a credit line to the material. If material is not included in the article's Creative Commons license and your intended use is not permitted by statutory regulation or exceeds the permitted use, you will need to obtain permission directly from the copyright holder. To view a copy of this license, visit http://creativecommons.org/ licenses/by/4.0/.

() The Author(s) 2018 